\title{
Curriculum Responsiveness in Teacher Professional Development Programmes: A Case Study of Language Education in Mauritius
}

\section{Aruna Ankiah-Gangadeen \\ Pascal Nadal}

\begin{abstract}
This article examines the way in which the Mauritian tertiary education sector is responding to the island's current socioeconomic and political context in an era of globalisation. We begin with a reflection on international trends in higher education and discuss how reduced state funding has led to the 'commodification' of education. In line with studies that stress the need for small island developing states (SIDS) to devise their own approaches rather than emulate bigger states, the imperative for more collaboration and concerted effort to optimise existing resources is emphasised. To support this stance, the paper leans on a study that examines the extent to which curriculum transitions between an academic undergraduate and a postgraduate teacher professional development programme, in the field of languages, are responsive to the needs of the country. The findings reveal that the high degree of duplication in both programmes and the lack of collaboration between the institutions concerned are impassive to the economic efficiency being targeted in the public tertiary education sector.
\end{abstract}

Keywords: commodification of education; curriculum transitions; economic efficiency; higher education; Small Island Developing States 


\section{Introduction}

There is some consensus that the advent of globalisation has led to the inclusion of education in the market economy. Consequently, it is expected that the sector will experience increased demand in the current context, where tertiary education is prized for professional upliftment with a growing number of service providers competing for a share of the state's higher education budget - which rarely keeps up with the demands of the expanding sector. Not surprisingly, the 'commodification' of education in response to tighter financial controls on higher education institutions by the state has led these institutions to consider and adopt alternative pathways to ensure constant student enrolment and sustain their existence. For instance, Knights (2003: 2) points out how international trade agreements like the General Agreement on Trade in Services (GATS), which 'identif[y] education as a service sector to be liberalised', have led to the internationalisation of education and because of cross-border education. Frontiers are becoming increasingly fuzzy in the face of international mobility, with foreign institutions opening branches in different parts of the world and a rise in student intake. The effervescence on the international scene prompts us to take a closer look at the scene in Mauritius, a small island developing state of close to 1.3 million people living on an area of about $2,040 \mathrm{~km}^{2}$. The island currently harbours 10 public and 48 private institutions catering for a population of about 50000 tertiary students. With no natural resources, Mauritius has had to review its economic policy and diversify its economy due to the fall in the price of sugar - the sugar industry having been the backbone of the Mauritian economy for a number of years after independence. While the textile and tourism industries are heavily banked upon in a bid to join the ranks of high income earning countries, Mauritius also aspires to become a world-class knowledge hub and gateway for postsecondary education in the region.

Against the aforementioned backdrop, this article explores the efficacy with which resources in higher education are being managed in the face of a limited student body, and also considering the Ministry of Education Culture and Human Resource's (MECHR) recognition that:

[i]f tertiary education is expected to contribute significantly to the building of skills and the intellectual capacity of the country, there are a number of critical challenges that have to be faced ... Both 
effectiveness and efficiency as well as an optimal use of financial resources have to be aspired for. (MECHR 2008: 14-15)

Furthermore, one of the goals of the Tertiary Education Commission (TEC), the regulatory body for tertiary institutions, is to '[e]nsure optimum use of the resources in the tertiary education institutions' (Ministry of Education and Scientific Research [MESR] 2006: 5-6), especially in a situation of overreliance on state funding. We especially focus on the field of teacher education, where a growing number of service providers compete to attract the same clientele.

\section{Small Islands Developing States versus Bigger States: Conceptualising One's own Model}

The apparent variance between worldwide trends in the provision of services in the academia and the realities that are inherent to higher education in a country like Mauritius may be discussed against the broader discourse of small island developing state's (SIDS) specificities in education. Indeed, there has been a growing literature over the last decades advocating the need for SIDS to delineate the contours of their educational landscape by using their own yardsticks, since they 'are not just small versions of large states. Rather, they have distinctive features that demand particular strategies for development' (Bray 2016: 6).

In fact, more than three decades ago, the distinctive features of SIDS - particularly with regard to the dearth of human resources in certain key sectors - were already being underscored. There was indeed a strong advocacy to come up with personal responses to economic, societal and cultural challenges (Commonwealth Secretariat 1986). Today this realisation seems to warrant a growing pertinence in the field of higher education, even if as a general observation, it appears that in their aspiration for economic prosperity, SIDS often look up to bigger nations as they chart their route to perceived notions of socioeconomic prosperity. This is often done without taking heed of contextual realities that are far remote from those of nations that SIDS seek to emulate (Nadal, Ankiah-Gangadeen \& Kee Mew 2017).

Instead of simply complying with international tendencies observed in academic circles, the educational priorities of SIDS (Crossley 2016: 12), 
should be driven by how they can 'respond to major external environmental and economic shocks and challenges'. One of the forms that this response can take is, for instance, by optimising information and communication technologies to expand the tertiary sector (Crossley 2016). In the case of Mauritius, this is precisely what has been witnessed with the setting up of the Open University of Mauritius, a new entrant in the field of public tertiary service providers that is already 'flexing its institutional muscle to challenge normative face-to-face models' (Samuel 2016: 195).

When transposed to the academia, the discourse on the optimisation of scarce resources available in SIDS often cites as examples the University of West Indies (UWI) and the University of South Pacific (USP). These island universities have stood the test of time with regard to the unique ways in which they have managed to pool the scarce resources available from their respective 'islands context' as a regional answer to the challenges posed by globalisation (Martin \& Bray 2011). Set up almost 70 years ago, the UWI, for instance, currently serves close to 40,000 students from 18 countries in the Caribbean region, across virtual and physical campuses located in different countries.

Bray (2011) recalls a similar intention to set up a regional university for small island states of the Indian Ocean region, like Mauritius, Seychelles, Reunion, Madagascar and the Comoros, in 1989. Advocated by the Indian Ocean Commission and backed by the heads of state of these respective countries, the projected setting up of an Indian Ocean university, nonetheless, did not come to fruition due to practical and political obstacles that surfaced further down the line. Since then, universities in this part of the world have been charting their own individual courses, despite some occasional initiatives (most often led by individuals rather than by the institutions themselves) like academic personnel visits or exchange programmes, collaborative research and publication endeavours, or the organisation of joint conferences. One recent illustration of the absence of sustained collaboration between regional stakeholders was witnessed with the setting up of the University of Seychelles in 2009. Even though the university chose to partner with a neighbouring institution for its BA French programme, namely the University of Reunion, it is best known as being a regional centre of the University of London, whose international programmes it offers. Moreover, in a bid to attract foreign students, the university aims to become 'the knowledge hub of the Indian Ocean' (University of Seychelles 2017), which precisely happens to be the way Mauritius positions itself as well (Gokulsing 2014). 


\section{Higher Education's Responses in Mauritius}

The response of higher education in Mauritius is characterised by the absence of concerted efforts among providers of tertiary education. This type of response is not only observed domestically in a country like Mauritius, where a tendency to construe of academic service providers solely in terms of competitors is clearly visible. It is also a feature on the regional front. Such a situation is contrary to the 'hub' philosophy, whereby universities refrain from considering each other solely in terms of competing service providers - as they can also be viewed as complementary agents - working to ensure that the hub offers a large and attractive range of study fields (Kalla \& Mootoocurpen 2015).

Even more surprising in the local context is the lack of collaborative pursuits amongst public institutions of higher learning, which often derive a substantial share of their budget from the government's coffers. In such a situation, it could have been expected that capitalising on the financial and human resources available would have represented an important concern for these institutions. Moreover, it might have also been a legitimate expectation that the Tertiary Education Commission or the ministry overseeing tertiary education would have seen to it that there is no duplication of offerings that target the same audience across campuses in close proximity to each other (see figure 1) in a small island state. Nevertheless, to attract more students, it was observed that each institution guarded its territory intensively and made its courses as market-oriented as possible.

One illustrative case in point about three public institutions of higher learning located a few metres apart from each in the area of Réduit, Mauritius, is that that they concurrently offer a number of courses that are either absolutely identical in nature or that have a number of common features. For instance, while students at the University of Mauritius (UOM) are reading for their B.A. (Hons) English on a full-time basis, so are other students following the same course in a similar full-time mode at the Open University of Mauritius (OUM). In addition, located in between these two aforementioned institutions, the Mauritius Institute of Education (MIE) offers to its B.Ed. (Hons) full-time English students, a number of literature and linguistics modules that are identical to those being offered as part of the BA English programmes at the UOM and the OUM. Moreover, the BA (Hons) English programmes at the two universities both comprise language didactics modules, the teaching of which 
constitutes the speciality of the MIE. This scenario stands as an illustration of a market-oriented approach prevailing in the local sphere, whereby institutions bank upon fields of study that are deemed to be lucrative. In Mauritius, teaching is viewed as an attractive profession as at times, it is the only option for students in the field of Humanities due to restricted job prospects on the island. Consequently, tertiary institutions offer courses that will guarantee a steady flow of intake irrespective of the fact that it may lead to duplication and, hence, not be financially viable for a small country.

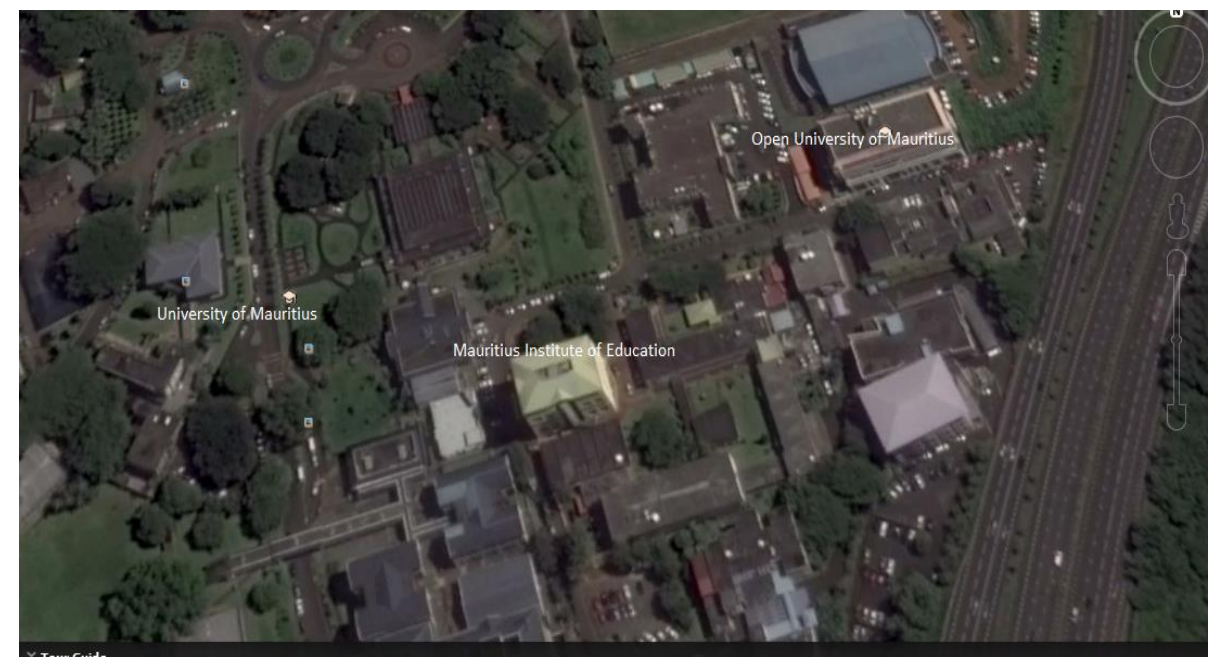

Figure 1: Google Earth snapshot view depicting the geographical proximity of public institutions of higher learning in the area of Réduit, Mauritius.

Whilst it may be argued that with the modern-day realities of the academia - governed by the logic of liberalisation - there is nothing objectionable per se with such a practice, yet the issue of rationalisation of resources brought about by considerations of size for a small island state like Mauritius cannot be overlooked in the present circumstances. This is crucial when we consider that the majority of the teaching resource persons of OUM are privately hired part-time lecturers who often work for other local public institutions of higher learning. We are concerned that instead of adopting an 
approach whereby the specific needs of individual institutions of higher learning are solely catered for on a case-to-case basis (Antoine 2017), regulatory bodies for the tertiary sector are silent about aligning programmes to student progression and career prospects, e.g. from university to teacher education institute for those contemplating teaching as a career. However, there is growing evidence of the opposite situation occurring, especially in the field of Teacher Education, as will be discussed later.

Nonetheless, amidst these manifestations of unresponsiveness at the level of transition from one tertiary institution to the other, the Open University of Mauritius constitutes an interesting case. Despite being a relative new comer $^{1}$ in the local academic landscape, the university markets itself as 'the fastest growing public university in Mauritius'. It has attracted more than 4000 students after just three years of operation (Open University of Mauritius 2017). Some of the characteristic features of this university include offering courses via distance mode with emphases on employability skills, optimal exploitation of the system of prior or experiential learning accreditation as defined by the Mauritius Qualifications Authority (MQA) ${ }^{2}$, and offering foundation courses for prospective students who might not possess the required qualifications to enrol for certain courses. In this sense, the university appeals to quite a large segment of the tertiary education clientele who might not be able to meet admission criteria imposed by other local institutions or who might not be able to afford the high costs associated with foreign universities. Consequently, the university's student enrolment rate is on the increase, recording a twenty percent rise for 2015 compared to the previous year. This

${ }^{1}$ The Open University of Mauritius was initially known as the Mauritius College of the Air, a parastatal body that operated under the aegis of the Ministry of Education since its inception in 1985 and that aimed at the promotion of arts, science and culture 'through mass media and distance education.'

(http://colfinder.net/materials/Supporting_Distance_Education_Through_Poli cy_Development/resources/worldbank/countries/mauritius/coa.htm)

${ }^{2}$ Functioning under the aegis of the Ministry of Education, the MQA is the local regulatory body that establishes and upholds regulations and provisions governing the validation (as per local and international standards) and accreditation of qualifications for employability and lifelong learning, in line with the National Qualifications Framework. 
situation even affords the university the capacity to generate the revenues needed to cover its operational costs, as government grants account for only ten percent of the university's budget (Antoine 2017).

Another key feature of the OUM seems to be its capitalisation on topup programmes that are meant to add up to previously earned qualifications either from the university itself or from other service providers. Two such examples concern the B.Ed. (Hons) Primary programme and the B.Ed. (Hons) in Early Childhood Education and Care. Whilst it is true that OUM provides an extended route for those applicants who need to start 'from scratch' with only 'A' level qualifications in hand, it is obvious that it targets the holders of the Diploma in Primary Education and the Diploma in Early Childhood Education (ECE) issued by the MIE as is evident from the profile of those who enrol on these courses. The practice of recruiting MIE diploma graduates may change as the MIE, which could until now offer qualifications up to diploma level only, was recently granted the much sought after 'degree awarding' status. Holders of the MIE Diploma in Primary Education and of the Diploma in ECE, indeed, constitute a select target profile for these degree programmes in what seems to be some sort of win-win situation for both the students (who could finally earn the much-awaited qualification) and the institution, whose student intake is boosted.

Viewed from a particular angle, OUM seems to be seen as providing tailor-made solutions that are in line with the genuine academic and professional aspirations of individuals seeking socioeconomic advancement. Whilst the absence of coordinated and articulated efforts for the whole tertiary education sector in Mauritius often leads institutions of higher learning to consider themselves as competitors rather than partners, it does seem that a few recent players in the field have managed to take advantage of the current situation by proposing courses and learning modes that complement offers made by other service providers. These new courses and learning modes seem particularly suited to the needs of the labour market and of the prospective labour force as well. The tendency for top-up programmes for students continues and is being strengthened, as yet another recently established institution, Université des Mascareignes ${ }^{3}$, has also positioned itself as an important provider of industry-relevant training (Betchoo 2016).

3 The Université des Mascareignes (UdM) has been founded in 2012 as a merger between the 'Institut Supérieur de Technologie' and the Swami 


\section{Higher Education in Mauritius: A Constantly Evolving Landscape}

With more Mauritian students now being able to afford studying abroad, a rise in the number of those who do so has been noted (Antoine \& Laurent 2017). Added to this trend, is increased competition from the private sector, which has led to admissions in most public institutions to experience a fall or sluggish intake (Tertiary Education Commission [TEC] 2016). Cost effectiveness in the public higher education sector then becomes a major preoccupation. A cursory look at student enrolment on certain courses at the Mauritius Institute of Education, the only institution that is officially mandated for teacher education on the island, reveals that figures can be as low as four students on certain programmes, e.g. the Full Time Teacher's Diploma Secondary (English) course, making it costly in terms of financial and human resources.

In many respects, a significant alignment of course offer and course content from one public institution of higher learning to the other could have been deemed a strong and sound response to the proliferation of private international academic service providers in Mauritius. Indeed, over the last decade, higher education institutions in Mauritius have flourished at an unparalleled rate. The vision of the previous government to have one graduate per home by 2020 and to transform the island into a knowledge hub for the region (Gouges 2011) has led to the liberalisation of tertiary education and to an increased access to it. Not only was the Open University of Mauritius set up to encourage enrolment through distance education, but a number of foreign universities such as Middlesex University, Aberystwyth University and Mauras College of Dentistry were allowed to open local branches. This was in addition to a number of institutions like the Mauritius Institute of Education, Charles Telfair Institute and the Médine Education Village establishing memoranda of understandings with foreign universities to run courses in a bid to attract those who wish to acquire foreign certification at a reduced cost. In 2015, there were no less than 45 Private Post-Secondary Educational Institutions (PESIs) on the island, out of which five were International Branch

Dayanand Institute of Management (http://udm.ac.mu/). It offers courses in areas like Business Management, IT, Engineering, and Sustainable Development, often in the form of double degrees awarded by the UdM itself and by its international partner, the University of Limoges, in France. 
Campuses and 92 overseas awarding bodies (TEC 2016) ${ }^{4}$.

A scrutiny of statistics published in the TEC Participation in Tertiary Education Report 2015 (TEC 2016) reveals that despite the proliferation of institutions and courses, there was a 3.3\% drop in enrolment rates in 2015. This can be explained by the fact that, as pointed out earlier, more Mauritian students are now choosing to study in reputed foreign institutions. Moreover, it would appear that the country has been unable to attract the targeted number of foreign students. Despite Mauritius's ambition to become a knowledge hub, of the 48970 students registered, only 1524 were foreigners, far less than the projected number of 100,000 foreign students by the year 2025 (Le Mauricien 2014). It is also worth pointing out that $40 \%$ of the foreign students are enrolled in the field of medicine. Unsurprisingly, the percentage of registered foreign students in local tertiary institutions fell when private institutions offering medical programmes ${ }^{5}$ were prohibited from running their courses due to accreditation issues either with the local regulatory bodies or with those of the country where the parent university is found, and because of various irregularities pointed out by students enrolled there (Le Mauricien 2014a). The drop in foreign student enrolment indicates that when it is hard to secure university admission in their home countries for a high status qualification like medicine, students turn to higher education institutions in Mauritius, which provides a ready market to meet their aspirations. When this ready market for medical studies shrinks, student enrolment falls as well. By contrast, areas of study that are more easily accessible elsewhere fail to attract foreign students and therefore, enrolment does not rise. The study by Kalla and Mootoocurpen (2015) sheds light on other factors that draw students to Mauritius. For example, some students are attracted to the intrinsic features of the country such as the good quality of life, personal safety and lower cost of tuition rather than the reputation of some universities, which often fail to emphasise the importance of research (Kalla \& Mootoocurpen 2015). We argue that the prevailing situation suggests that the Mauritian higher education sector is not being managed efficiently to reach its projected objectives.

${ }^{4}$ Some of foreign universities that agreed to partnerships and memoranda of understanding with local institutions are: University of Brighton, the University of KwaZulu-Natal, the University of Paris II Pantheon Assas, Curtin University and the University of Northampton.

${ }^{5}$ Mauras School of Dentistry and D.Y. Patil are two well-known cases in point. 


\section{Curricular Responsiveness: A Case Study of Educational Transition at Level Three}

In this part of the article, we take a closer look into curricular responsiveness at tertiary level (Griesel 2002; Ogude et al. 2005) by studying the phenomenon of educational transition at level three, namely from university to a teacher education institute in Mauritius. As pointed out by Van Schalkwyk (2010: 4), 'university responsiveness is variously understood and applied' and 'there have been no concerted attempts to resolve the conceptual confusion that surrounds the notion of responsiveness in higher education' (Van Schalkwyk 2010: 33). For instance, responsiveness is often taken to mean the extent to which higher education courses offered: i) answer the needs of the labour market; or ii) help in achieving society's aspirations, or iii) manage in fulfilling policies defined by the State. When coupled with the notion of transition (e.g. from secondary schooling to tertiary studies), responsiveness is associated with the relative degree of ease with which students effect the shift to a new learning paradigm as they leave high school to embark upon university studies. In addition, university responsiveness in the $21^{\text {st }}$ century obviously encompasses the notion of relevance to macro orientations that are directly or subtly imposed by global forces, since all institutions of higher learning operate as players within a broader field of local, regional and international service providers.

In line with the idea spelt out by Jongbloed et al. (2008), Van Schalkwyk (2010) also points out that more and more, the concept of responsiveness is being substituted by that of engagement, in the sense that the latter includes the notion of accountability. Far from being just desirable (as is the case with responsiveness), engagement constitutes a more forceful petition in favour of the necessity for institutions of higher learning to fulfil a set of duties towards the society and country within which they locate themselves. In the context of the present discussion, there is scope to consider the element of engagement, given that the notion of transition here relates to the move that graduate students make to embark upon a teaching career in an institution dedicated to Teacher Education. Moreover, as tertiary institutions under consideration are financed by public funds, it is expected that they operate in ways that optimise the utilisation of available resources.

As we embark on the case study, we are driven by the economic rationale behind curricular alignment, given the emphasis laid by the Ministry of Education on the need for private tertiary institutions to be cost-effective. 
Consequently, our focus is crucial since the sector is plagued by a number of weaknesses, such as limited capacity of post-secondary education institutions locally, lack of infrastructure and related amenities (e.g. accommodation on campus), shortage of expertise in emerging and new thrust areas, difficulty with recruitment and retention of high-level faculty, and over reliance on state funding in a context where the economic downturn on the international scene is impacting negatively on the local economy (TEC Strategic Plan 2007-2011. 2007).

The institutions under scrutiny are the Mauritius Institute of Education and the University of Mauritius. Set up in 1973, the Mauritius Institute of Education is a parastatal body that operates under the aegis of the Ministry of Education and Human Resources. The institution is mandated to engage in educational research, curriculum development and teacher education. It runs a plethora of programs, namely Ed.D., Ph.D., M.A., B.Ed., PGCE, Teacher's Diploma, and Teacher's Certificate.

The University of Mauritius was founded in 1965 and its main activities comprise research, consultancy, and teaching. During the last two years (2015-2016), the university ran no less than 180 programmes at both undergraduate and post-graduate levels. The two courses under scrutiny here are the PGCE Full Time (English) offered at the MIE and the B.A. Honours (English) offered by the UOM.

The PGCE Full Time course targets pre-service English teachers and has been conceived as a top-up certificate which aims to equip language graduates with pedagogical know-how, given that in the local context, as mentioned earlier, most language graduates contemplate a career in teaching due to the dearth of alternative prospects. It can be said that it is essentially in response to this market demand that the UOM incorporated didactics modules in its BA Honours English and French Courses. The reason for which we have focused on language and literature programmes is because most of those who enrol on these courses identify teaching as their first preference when it comes to charting the course of their professional career. Much more than for other fields of study, the correlation between language and literature learning at university level and the ensuing prospect of later teaching the subject is a strong one. The correlation explains why modules of language and literature didactics feature prominently - sometimes as core items - in most undergraduate language programmes on offer at university, contrary to the situation in other fields of study. The B.A. languages programmes therefore constitute a very 
appropriate case study for the discussion of transition from university to Teacher Education institution.

Moll's (2004) multi-faceted model of curriculum responsiveness (see figure. 2), which examines curricular responsiveness at the economic/policy, institutional \& cultural, disciplinary, and pedagogical/learning levels, will be used to determine the extent to which the two institutions are responsive to the socio-political context. This model is deemed to be appropriate because it encompasses the main factors that the literature on curricular responsiveness foregrounds (Ogude et al. 2005; Van Niekerk 2009). For the purpose of the case study, however, we chose to focus on economic/policy responsiveness, institutional \& cultural responsiveness, as well as disciplinary responsiveness, which are more relevant to the phenomenon we are examining. Due to the macro perspective of the argument we are advancing, we did not engage with the pedagogical/learning responsiveness, which required specific data from lecturers and students.

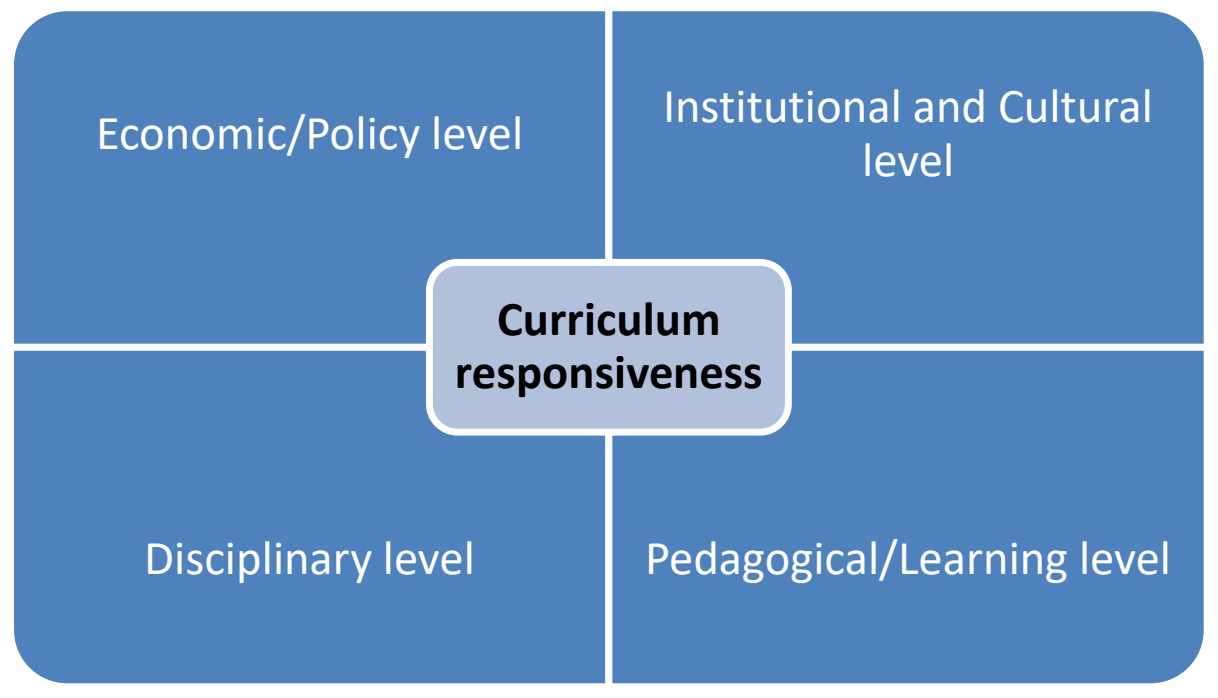

Figure 2: Moll's multi-faceted model of curriculum responsiveness.

\section{Discussion}

Economic/policy responsiveness refers to the extent to which universities are addressing the needs of the labour market by producing qualified and skilled 
human resources. A comparison of the aims of the PGCE Subject Didactics I (English) module and those of the B.A. (Hons) English Language Teaching: Theory and Practice module reveals the high degree of similarity between the two modules (see Annex 1 for aims of modules). It is evident that both institutions are catering for the labour market by enabling prospective teachers to be adequately equipped with the requisite knowledge, skills and attitude to become effective practitioners. The provision of such programmes, or components within programmes, certainly contributes to the professionalization of the teaching personnel in schools. Previously, in Mauritius, graduates without pedagogical know-how were recruited as teachers. Now, there is little doubt that developing knowledge of pedagogy prior to embracing a teaching career impacts positively on the classroom, as it helps the teacher to gear his/her approach towards learners' needs.

Insights afforded by the case study clearly reveal that the two institutions of higher education are not adequately responsive to the situation in the education sector. There is a need for inter-institutional dialogue and partnership to ensure the optimisation of resources available and enhance economic responsiveness, especially in a context where internationalisation threatens to undermine public sector service providers. The echoes noted with respect to such elements as course content and school placement can be eliminated through the alignment of courses and or modules offered, and close inter-institutional collaboration can lead to the promotion of disciplinary responsiveness. In short, the indications are that institutions should adhere to the fields in which they specialise instead of crossing boundaries in a SIDS with a small target population.

Moreover, the extent to which applied practice by both institutions is similar (e.g. instance, placement in schools - especially in a situation where most of the trainees who enrol on the PGCE FT course are UOM graduates), prompts us to question the economic viability of these courses from the perspective of the State, which provides funding to the two teaching institutions. The duplication of content is clearly indicative of a waste of logistics at various levels, namely human resources, infrastructure and material. Furthermore, placement in secondary schools is becoming increasingly problematic given the limited number of schools and the increasing number of trainees that the MIE and UOM send every year on traineeship. Thus, while on the one hand the two institutions appear to demonstrate disciplinary responsiveness by providing knowledge and developing skills that are highly 
relevant to the needs of the trainees, the movement from a mono-disciplinary to a multi-, inter- and trans-disciplinary focus becomes questionable, precisely in terms of such duplication and wastage.

A consideration of institutional and cultural responsiveness leads us to an observation by Ekon and Cloete (in Ogude et al. 2005: 7) that '(i)nstitutionally and culturally responsive curriculum at tertiary level should lead to 'new types of knowledge production and dissemination' with a view to contributing to "productivity and competitiveness". The case under scrutiny confirms observations made earlier in the paper since, by mirroring the content of their courses, the MIE and UOM are increasing the already existing competition in a small saturated market with regard to both student intake and academic productivity. Conversely, inter-institutional collaboration could have paved possibilities to broaden the scope for students, meet varied market needs more effectively, as well as promote institutional and cultural responsiveness by allowing for more flexibility in shaping the course according to students' needs and areas of interest. It is therefore imperative that institutions are guided by the national agenda rather than their individual agenda in strategic planning. Institutions should engage in dialogue and operate in line with the socio-political context in order to contribute to the advancement of society rather than, as pointed out earlier, adopt a territorial attitude and compete with one another. While a 'survival of the fittest' situation can benefit a few institutions, devising complementary programmes will certainly ensure the optimal use of available resources, thereby enabling the national agenda to progress. These observations will surely be enriched by findings from the forthcoming stages of the ongoing study on language education in Mauritius and also from similar endeavours being undertaken locally, e.g. to investigate the phenomenon of transition at level 3 for Science students moving from university to teacher education.

\section{Conclusion}

Given the limitations with regard to the student population and available resources, small island developing states, we deduce, cannot blindly follow in the footsteps of large states. The Ministry of Education and other regulatory bodies have a primary role in ensuring the effective running of public institutions, especially in the face of fierce competition from the private sector. By failing to devise policies that foster collaboration and concerted effort, 
policy makers are in fact sharpening the spirit of competition that turns out to be detrimental to state economy and any attempt made to meet the students' needs. A higher education curriculum that is more responsive in the different respects spelt out in this article will ensure clearer and more serene growth perspectives for individuals envisaging a smooth progression along the education professional development continuum as well as for institutions, in full compliance with their mission, vision, mandate and specificities as educational service providers. At macro level, this could warrant a secure pathway to achieving the country's vision of becoming a regional hub for higher education by tapping on the best possible utilisation of the human and financial capital available. As long as this is not deemed desirable and feasible domestically, it seems almost unthinkable to envisage partnership initiatives with neighbouring countries sharing similar socioeconomic imperatives and geopolitical features, in the way that it has been done elsewhere by other small island states.

\section{References}

Antoine, R. 2017. 5e Anniversaire de l'Open University: À la Conquête du Continent Africain. Defimedia.info. Available at: http://defimedia.info/ 5e-anniversaire-de-lopen-university-la-conquete-du-continent-africain.

(Accessed on 14 July 2017.)

Antoine, R. \& T. Laurent 2017. Universités: Le Taux d'inscription en Baisse Constante. Defimedia.info. Available at: http://defimedia.info/universites-le-taux-dinscription-en-baisse-constante (Accessed on 10 October 2017.)

Betchoo, N. 2016. The Relevance of Top-up Degree Programmes for Career Advancement of Business Students. International Journal of Scientific Research 1,2:82-89.

Bray, M. 2016. Higher Education in Small States: Evolving Patterns in the Context of Globalisation. Island Studies Indian Ocean/ Océan Indien 3,1: 6-9.

Bray, M 2011. The Small States Paradigm and its Evolution. In Martin, M. \&

M. Bray (eds.): Tertiary Education in Small States: Planning in the Context of Globalization. Paris: IIEP. 
Commonwealth Secretariat. 1986. Educational Development: The Small States of the Commonwealth. Report of a Pan-Commonwealth Experts Meeting, Mauritius, 1985, Education Programme. London: Commonwealth Secretariat.

Crossley, M. 2016. Rethinking, Applying and Extending Research on Education in Small States. Island Studies Indian Ocean/ Océan Indien 3,1:10-13.

Gokulsing, D. 2014. Positioning Mauritius as a Knowledge Hub in the Context of Globalisation. In Proceedings of ICETSR, Malaysia Handbook on the Emerging Trends in Scientific Research. Pak Publishing Group.

Gouges, G. 2011. MAURITIUS: Minister Outlines Knowledge Hub Plans. University World News. Issue No. 191. Available at: http://www.univer sityworldnews.com/article.php?story=20111001152158418. (Accessed on 14 July 2017.)

Griesel, H. 2002. Universities and the World of Work: A Case Study on Graduate Attributes. In Council on Higher Education, Relations between Higher Education and the Labour Market. Available at: http://www. che.ac.za/documents/d000037/Colloquium_Report.pdf. (Accessed on 1 February 2017.)

Jongbloed, B., J. Enders \& C. Salerno 2008. Higher Education and its Communities: Interconnections, Interdependencies and a Research Agenda. Higher Education 56,3: 303-324.

Kalla, S. \& A. Mootoocurpen 2015. Éducation Tertiaire : Maurice, Centre du Savoir en Devenir. Business Magazine (No. 1186). Available at: http://www.businessmag.mu/article/education-tertiaire-maurice-centredu-savoir-en-devenir. (Accessed on 1 February 2017.)

Knights, J. 2003. GATS, Trade and Higher Education. Perspective 2003: Where are we? The Observatory on Borderless Higher Education. Information Strategic Information Service. Available at: www.obhe.ac.uk. (Accessed on 1 February 2017.)

Le Mauricien. 2014. Etudiants étrangers au tertiaire: Maurice, une porte ouverte sur le monde. Available at: http://www.lemauricien.com/article/ etudiants-etrangers-au-tertiaire-maurice-porte-ouverte-sur-monde.

(Accessed on 1 February 2017.)

Le Mauricien 2014a. Enseignement Supérieur: Le DY Patil Medical College sur la Sellette. Available at: http://www.lemauricien.com/article/ enseignement-superieur-dy-patil-medical-college-sur-la-sellette. 
(Accessed on 29 July 2017.)

Martin, M. \& M. Bray (eds.) 2011. Tertiary Education in Small States: Planning in the Context of Globalisation. Paris: IIEP.

Ministry of Education. Cf. http://colfinder.net/materials/Supporting_Distance _Education_Through_Policy_Development/resources/worldbank/countri es/mauritius/coa.htm.

Ministry of Education and Scientific Research. (MESR) (Republic of Mauritius) 2006. Developing Mauritius into a Knowledge Hub and a Centre of Higher Learning. Mauritius: Ministry of Education and Scientific Research.

Ministry of Education, Culture and Human Resources. (MECHR) 2008. Draft Education and Human Resources Strategy Plan 2008-2020. Mauritius: Ministry of Education, Culture and Human Resources.

Moll, I. 2004. The Anatomy of a Concept. In Griesel, H. (ed.): Curriculum Responsiveness: Case Studies in Higher Education. Pretoria: South African Universities' Vice-Chancellors' Association (SAUVCA).

Nadal, P., A. Ankiah-Gangadeen \& E. Kee Mew 2017. In Jules, T. \& P. Ressler (eds.): Is 'Small' Always Small and 'Big' Always Big? Re-reading Educational Policy and Practice in Small States. Berlin: Peter Lang.

Ogude, N., H. Nel \& M. Oosthuizen 2005. The Challenge of Curriculum Responsiveness in South African Higher Education. Available at: http://www.che.ac.za/sites/default/files/publications/d000132_Ogude-etal_Curriculum_responsiveness_SA_HE.pdf. (Accessed on 1 February 2017.)

Open University of Mauritius. 2017. Why Study at Open University? Available at: http://www.open.ac.mu/. (Accessed on 1 February 2017.)

Samuel, M. 2016. In Samuel, M. \& H. Mariaye (eds.): Continuity, Complexity, and Change. Teacher Education in Mauritius. Illinois: Common Ground.

Tertiary Education Commission (TEC) 2016. Participation in Tertiary Education (Report 2015). Réduit, Mauritius: Tertiary Education Commission.

Tertiary Education Commission (TEC) 2007. Strategic Plan 2007-2011.

Réduit, Mauritius: Tertiary Education Commission. Available at: http://www. tec.mu/pdf_downloads/pubrep/TEC\%20Strategic\%20Plan \%202007-2011.pdf. (Assessed on 1 February 2017.)

University of Seychelles. 2017. Research Policy and Procedures. Available at: 
http://unisey.ac.sc/index.php/component/content/article/10-researchconsultancy/134-research-policy-and-procedures. (Accessed on 1 February 2017.)

Van Niekerk, R. 2009. Economic Responsiveness in Organisational Psychology Curricula. Unpublished Master's Thesis. Rhodes University, South Africa.

Van Schalkwyk, F. 2010. Responsiveness and its Institutionalisation in Higher Education. Unpublished Master's Thesis. University of the Western Cape, South Africa.

\section{Annexure 1}

\begin{tabular}{|c|c|}
\hline MIE English Subject Didactics I & $\begin{array}{c}\text { UOM English Language Teaching: } \\
\text { Theory and Practice }\end{array}$ \\
\hline $\begin{array}{l}\text { Aim } \\
\text { To provide trainees with an } \\
\text { overview of main approaches } \\
\text { underpinning the teaching, } \\
\text { learning and assessment of } \\
\text { English language at } \\
\text { secondary level. } \\
\text { Learning Outcomes } \\
\text { Trainees should be able to: } \\
\text { - Demonstrate an } \\
\text { understanding of theories } \\
\text { pertaining to language } \\
\text { acquisition/learning } \\
\text { - Situate English language } \\
\text { teaching at secondary level } \\
\text { within the linguistic contexts } \\
\text { prevailing in Mauritius } \\
\text { Describe the different } \\
\text { approaches for the teaching of } \\
\text { English and literature }\end{array}$ & $\begin{array}{l}\text { Aim } \\
\text { Familiarize students with some } \\
\text { of the literature on } \\
\text { second/foreign language } \\
\text { teaching } \\
\text { Objectives } \\
\text { - Encourage students to explore, } \\
\text { analytically and critically, some } \\
\text { curricula/reports/articles on } \\
\text { English and English language } \\
\text { teaching in Mauritius; } \\
\text { - Introduce students to the notion } \\
\text { that as potential teachers, they } \\
\text { can make informed choices and } \\
\text { carefully select from the panoply } \\
\text { of existing approaches and } \\
\text { methods in order to respond to } \\
\text { the needs of their students and to } \\
\text { the challenges of their English } \\
\text { language teaching contexts; }\end{array}$ \\
\hline
\end{tabular}


- Demonstrate awareness of different types of tools used for assessment in English language and literature.
- Consider some of the key decisions that teachers make and key issues that they have to deal with.

Aruna Ankiah-Gangadeen

Mauritius Institute of Education

Mauritius

a.ankiah@mieonline.org

Pascal Nadal

Mauritian Diocesan Service of Catholic Education

Mauritius

nadalmauritius@gmail.com 